4. Лола А. М. Городское и агломерационное управление в России: состояние и что делать. - М.: «Канон+» РООИ «Реабилитация», 2013.: ил.

5. Самарско-Тольяттинская агломерация // Официальный сайт Министерства экономического развития, инвестиций и торговли Самарской области. URL: http://www.economy.samregion.ru/activity/mun_razv/samtolagl/samarsko-tolyattinskaya-aglomeratsiya/

\title{
Khankishiyeva E.M. Revival of gold mining industry in the regions of Azerbaijan
}

Institute of Economics of the National Academy of Sciences of Azerbaijan (Azerbaijan, Baku)

doi:10.18411/sciencepublic-08-07-2019-07

idsp: sciencepublic-08-07-2019-07

The development of the gold mining industry in Azerbaijan contributes to the birth of one of the most strategically important sectors of the republic's economy. Azerbaijan is one of the few countries with sufficient reserves of gold, and therefore, the efficient growth of the economy depends on the effective exploitation of its deposits and the rational use of mined metal. Therefore, the study of individual problems of this industry is of particular importance for the republic.

The purpose of the research is developing scientifically based recommendations for determining the prospects for the development of the gold mining industry of the Republic of Azerbaijan and its degree of influence on the sustainability of the country's economy as a whole. The research determined the importance of the mineral resource base of gold in the modern economy of the republic, identified the possibility of adapting foreign (Australian) experience of innovative development to domestic conditions, investigated the conditions of development and the degree of revival of the gold mining industry in Azerbaijan. Based on the expert assessment of the strengths and weaknesses of gold mining enterprises, as well as opportunities and threats from the environment, the SWOT-analysis method has been adapted to assess the effectiveness of the economic activities of gold mining companies. The results obtained allow the management of gold mining companies to use the proposed form of structuring external and internal environment factors, which can be considered as a tool for the formation of strategic alternatives aimed at achieving the goals of the enterprise.

A comprehensive review of the current state of the country's gold mining industry, followed by shaping the prospects for its development in the near future, led to the conclusion that the gold mining industry of Azerbaijan, as a young industry, has a promising future. In Azerbaijan, there is an urgent need to ensure its own economic and defense security. In this regard, the role of own gold mineral resource base in ensuring balanced development of economic sectors is extremely important.

The gold mining industry in Azerbaijan is characterized by a combination of such favorable factors as low operating costs and huge opportunities for production growth in the future. There are several world-class gold deposits in the country, in the depths of which large deposits of high-quality ore are hidden. Moreover, many of them were begun to mine gold quite recently, or the start of production is planned for the near future. This situation is very different from the state of the industry in other largest gold suppliers countries, where there has been a decline in production over the past five years.

All this requires the development of a balanced program for the long-term development of the country's mineral resource base and taking into account the possibility of more active participation in the global mineral resource market.

$$
* * *
$$

1. Khankishiyeva E.M. Gold mining industry as a young branch of the economy of Azerbaijan/ / News of Azerbaijan National Academy of Sciences / Economy Series №1 2013. Baku-2013 p.159

2. Khankishyieva E.M. / Improvement of gold mining methods associated with the evolution of human society/ The International Scientific Association of Economists "Consilium" International scientific periodical journal for economists and jurists "The genesis of genius". Geneve, Switzerland, 1 December 2014 \#3 p.73 